\title{
THE FIRST TEN YEARS OF SELBY GARDENS
}

\author{
CARlyle A. Luer \\ 3222 Old Oak Drive, Sarasota, FL, 34239-5019, U.S.A. \\ cluer@juno.com
}

\begin{abstract}
AвSTRACT. In her will, Marie Selby left her home and grounds to be used as a "botanical garden" at the discretion of the directors of Palmer Bank. The property was zoned for high-rises, but opposition to a botanical garden was overcome. Cal Dodson, Professor of Botany at the University of Miami, was a chosen as a director. The Gardens soon acquired more grounds and staff. A volunteer program was begun, and volunteers contributed vastly to our rapid growth. Our many accomplishments include the quarterly Bulletin, first appearing in spring 1974, and the scientific journal, Selbyana, first published in January 1975. The growth of the Gardens would inevitably accelerate with the great infrastructure put in place during our first ten years.
\end{abstract}

Key words: William Selby, Marie Selby, Sarasota, botanical garden, Calaway H. Dodson

Bill and Marie Selby built their retirement home in Sarasota on the bay front in the early 1920s. Bill had amassed a fortune with Texaco Oil Company. Without heirs, they created the charitable William G. and Marie Selby Foundation with Palmer Bank as trustee. I knew Mr. Selby, only in consultation in his terminal illness in 1956. I cared for Mrs. Selby's surgical problems, but I knew nothing about her intention of leaving her home for a "botanical garden." Only in June 1972, one year after her death, were conditions of her will announced at a meeting of the board of Palmer Bank. By coincidence, I was in attendance. I had been a director for six or seven years, not because I knew anything about banking, but because of my surgical practice.

In her will, Mrs. Selby left her home and grounds with the adjacent vacant lot to the north, to be used as a "botanical garden" at the discretion of the directors of Palmer Bank. She had purchased the lot to the north, also on the bay, where the home of Russian Prince Michael Cantacuzene once stood, to prevent the construction of a high-rise. Her idea of a botanical garden had been a pretty garden where she could hold garden club meetings and social events. For maintenance, she designated a small endowment, all the rest of her estate reverting to the Selby Foundation. The endowment with the proceeds from the sale of her property would also revert to the Foundation, at the discretion of Palmer Bank.

Bill Coleman, the chairman of the board of Palmer Bank, was a friend of ours. We shared an interest in nature, and had made field trips into the Fakahatchee Swamp. I explained to the board the possibility of creating a true botanical garden, but there was no enthusiasm. Zoned for high-rises, her seven-acre property must have been worth a fortune. Privately, I described the potentialities to Coleman, and he was receptive. He was a forceful chairman, so during the summer of 1972, it was decided that there would indeed be a Marie Selby Botanical Gardens.

Consultants from the New York Botanical Garden and the University of Florida agreed that specializing in one small group of plants such as orchids would be feasible. Several alternative, larger sites east and south of Sarasota were investigated, but her home with seven acres of land near downtown Sarasota was finally decided upon, but not without considerable reservations. The property was zoned for high-rises, not a botanical garden. There was considerable opposition to a botanical garden from more than one source. All kinds of questions were raised by the city commission, and the city building, planning, and zoning boards. It seemed like one roadblock after another was being thrown in our path. Were we to become an amusement

\footnotetext{
* This paper was prepared in the framework of the celebration of Lankester Botanical Garden's $40^{\text {th }}$ anniversary.
} 
park? Where would cars park? How about traffic? How about your neighbors? How about pollution? Would anything be sold? Could we be taxed? By the end of 1972, a special exemption for a botanical garden was granted reluctantly by the city. We applied for and received tax-exempt status from the IRS to become a charitable institution.

Next, a director had to be found. Cal Dodson, Professor of Botany at the University of Miami, at that time on a year sabbatical in Ecuador, was a candidate. In January 1973, Bill Coleman, his wife and their daughter, and Jane and I flew down to Ecuador to discuss the situation with him. Dodson thought that the proposition seemed too good to be true, that new botanical gardens were not being made any more. He was not aware of the impending Lankester Garden. He reasoned that if the scope of the garden were restricted to one small group of plants, such as epiphytes, it might fit on the small piece of land allotted. He accepted the offer. Abandoning his tenure with the University of Miami and his sabbatical, he and his family arrived in Sarasota the following month.

In February 1973, the Dodson family moved into the moldy Selby house that had been closed for over 18 months with a leaking roof before they found a place to live. Mrs. Selby's yard had become a massive jungle of weeds and Brazilian pepper trees during the last 20 years of her life. Months were spent clearing the invasive plants. Where to place what kinds of greenhouses and where to place the walkways had to be decided.

Among the first employees were two gardeners who had worked for Mrs. Selby. In April 1973, Dodson hired Ruby Hollis, who became a masterful secretary and backbone of administrative duties for the next generation. Hans Wiehler and Kiat Tan, doctoral candidates in botany from the University of Miami, were brought to the Gardens as staff members.

Soon after our beginning in 1973, one of our most important acquisitions with Selby Foundation funds was the botanical library of William Cole of Winter Park. From him and Weldon and Wesley, rare book dealers in England, we obtained famed treasures such as Bateman's Orchidaceae of Mexico and Guatemala as well as his Monograph of Odontoglossum, Lindley's Sertum Orchidaceum, Linden's Pescatoria, Warner's Select Orchidaceous Plants, Warner and
Williams' The Orchid Album, a complete run of Curtis' Botanical Magazine, and Woolward's Monograph of Masdevallia.

An attractive, substantial "gate house," with a front reception desk, restrooms, and plant shop, was built in 1973 and opened to the public with a dedication ceremony in January 1974. The property across the street from the gate house, and the adjacent lot and house to the north, were acquired for parking, and the corner house by highway 41 was acquired for "administration," all with grants from The Selby Foundation in 1973. Across the street from the newly acquired administration building was the Payne mansion (also on the bay and zoned for a high rise) that belonged to Dr. Paulk, an orthodontist and friend of ours. After negotiations, the price agreed upon for the Payne house was paid by the Selby Foundation and a donor, so by the summer of 1973 we had considerably expanded the physical scope of the Gardens.

During the summer of 1973, the Gardens hosted its first visiting botanical scientist, Dr. Richard Keating of Southern Illinois University. $\mathrm{He}$ and his family lived on the grounds. Also that summer, the Gardens' official seal with four epiphytic species (an orchid, a bromeliad, a gesneriad, and a Peperomia) and the date 1973 was designed on our kitchen table.

Greenhouses were completed in the summer of 1974. In the largest one close to the gate house, we built a meandering trellis-covered walkway beside a massive, rugged, cliff-like wall of "lava rock" boulders, dripping wet and festooned with lush vegetation. It became the display house. Workers, volunteers, and many visitors came and went.

Paid memberships in the Gardens were begun. A volunteer program was started without which we could not have existed. Volunteers contributed vastly to our rapid growth. One of their many accomplishments was the quarterly Bulletin, the first number appearing in spring 1974. The first issue of Selbyana, the scientific journal, was published in January 1975.

Our small endowment was dwindling. Our new Selby Gardens Board of Directors of only five members eliminated the expensive services of an outside accounting firm, and gained complete independence from Palmer Bank, under which we had been a dependent and charged a fee. Even after elimination of the above losses of revenue, our income from the 
endowment was so meager, we could scarcely survive. On at least one occasion, a donor made the payroll.

In July 1975, we decided that we would start charging visitors a fee of one dollar. Already open a year and a half, none of us thought that this date would be cited incorrectly, some 30 years later, as the "beginning" of Selby Gardens.

Meanwhile, Dodson initiated a student internship program, and an orchid identification service. Harry Luther in bromeliads, John Atwood in orchids, and Mike Madison in aeroids joined us. Dr. Raven, director of the Missouri Botanical Garden, came down for the formal dedication of the Gardens, a gala reception held 3 April 1976. The Selby Foundation promised a certain amount of financial aid for each of our first five years to help with capital improvements, but that ceased after four.

The next acquisition of land, purchased by a donor, was the frame house on Orange Avenue with an existing driveway, next door to the building that presently houses the library. This would give us a second access to the Gardens, but the city said 'no,' because it would be 'too dangerous' near the busy intersection of 41 and Orange. After arguing our case before a hostile city commission, Ken Thompson, the city manager, said, 'let them try it.' Begrudgingly, Ken's suggestion was allowed. Of course, it worked, but we agreed that the exit would be limited by a 'no left turn.' Nothing more was ever heard.

The next acquisition was the two-story, frame house east of the administration building, purchased mostly from donated funds. It was used as student quarters until it was demolished for more parking.
The corner building, previously a dental office, then insurance office, but now the library, was acquired next with funds from the Selby Foundation, Eric Young, an English philanthropist, and donors. It became known as the EYMC, the Eric Young Micropropagation Centre, which eventually failed and was abandoned.

Volunteers worked tirelessly on exhibits, luaus, plant sales, auctions, and all kinds of social events to raise money. Money was always a problem. We spent money we did not have, but we had tremendous assets, so there was never a possibility of our facing bankruptcy. Had we always waited until we could afford something, we would have been still sitting in Mrs. Selby's house. We were in debt, but by the end of eight years, our financial picture was looking better. Income from sales, special events, and donations was increasing, and the debt was decreasing.

The board had been expanded to include bankers who thought a new director was necessary. A retired Air Force General was hired to replace Dodson who was made Director of Research. Camaraderie and enthusiasm vanished. Volunteers were alienated. A promised research building with endowment from Jesse Cox failed to materialize. With fancy charts, the new director general "proved" how much the greenhouses with extensive collections, such as aeroids and gesneriads, were wasting money. He decided to convert a large, valuable greenhouse into a room for meetings and social events. After the slow years that followed, the growth of the Gardens would inevitably accelerate with the great infrastructure already in place. It could not fail, and it did not fail. The momentum regained in the last 30 years has been phenomenal. 
